\title{
Encyclopedia of Multimedia Technology and Networking
}

\section{Second Edition}

Margherita Pagani

Bocconi University, Italy

\section{Volume II \\ Ex-N}


Director of Editorial Content: Kristin Klinger

Senior Managing Editor: Jennifer Neidig

Managing Editor: Jamie Snavely

Assistant Managing Editor: Carole Coulson

Cover Design: Lisa Tosheff

Printed at: $\quad$ Yurchak Printing Inc.

Published in the United States of America by

Information Science Reference (an imprint of IGI Global)

701 E. Chocolate Avenue, Suite 200

Hershey PA 17033

Tel: 717-533-8845

Fax: 717-533-8661

E-mail: cust@igi-global.com

Web site: http://www.igi-global.com/reference

and in the United Kingdom by

Information Science Reference (an imprint of IGI Global)

3 Henrietta Street

Covent Garden

London WC2E 8LU

Tel: 442072400856

Fax: 442073790609

Web site: http://www.eurospanbookstore.com

Copyright $($ C 2009 by IGI Global. All rights reserved. No part of this publication may be reproduced, stored or distributed in any form or by any means, electronic or mechanical, including photocopying, without written permission from the publisher.

Product or company names used in this set are for identification purposes only. Inclusion of the names of the products or companies does not indicate a claim of ownership by IGI Global of the trademark or registered trademark.

Library of Congress Cataloging-in-Publication Data

Encyclopedia of multimedia technology and networking / Margherita Pagani, editor. -- 2nd ed.

$$
\text { p. cm. }
$$

Includes bibliographical references and index.

Summary: "This publication offers a research compendium of human knowledge related to the emerging multimedia digital metamarket"--Provided by publisher.

ISBN 978-1-60566-014-1 (hardcover) -- ISBN 978-1-60566-015-8 (ebook)

1. Multimedia communications--Encyclopedias. I. Pagani, Margherita, 1971-

TK5105.15.E46 2009

$621.38203--\mathrm{dc} 22$

2008030766

British Cataloguing in Publication Data

A Cataloguing in Publication record for this book is available from the British Library.

All work contributed to this encyclopedia set is new, previously-unpublished material. The views expressed in this encyclopedia set are those of the authors, but not necessarily of the publisher.

If a library purchased a print copy of this publication, please go to http://www.igi-global.com/agreement for information on activating the library's complimentary elecironic access to this publication. 


\title{
Multimedia for Direct Marketing
}

\author{
Ralf Wagner \\ University of Kassel, Germany \\ Martin Meißner \\ Bielefeld University, Germany
}

\section{INTRODUCTION}

Multimedia technologies provide direct marketers with an incredible diversity of opportunities for communication to as well as with customers in a more appealing manner than old-fashioned printed advertisements or mailings (Coviello, Milley, \& Marcolin, 2003). Direct marketing is one of the most important application domains of innovative multimedia products. An increasing share of marketing spending is invested in network activities, particularly WWW advertising and online shops. Online marketing activities have become so prominent that the 2000 Superbowl has been labeled the "Dot com Bowl" (Noe \& Parker, 2005).

In this article, we outline:

- how companies improve their business by multimedia and networks, and

- the challenges for direct marketing brought about by multimedia.

The remainder of the article is structured as follows: in the first section, we provide a definition of direct marketing, illustrate the opportunities opening up for marketers by the new technologies, and present a scheme of tasks in direct marketing. Additionally, we describe the features of direct marketing using multimedia in the four domains of product, price, place, and promotion. In the subsequent section we address the possibilities for contemporary relationship marketing in the framework of content, commerce, and community. Thereafter, we discuss innovative direct marketing activities using the examples of advertising in personalized digital TV environments and mobile telephony. The article concludes with a comparison of different direct marketing media and a synopsis of success factors.

\section{DIRECT MARKETING: DEFINITIONS AND TASKS}

According to the American Marketing Association (2006), the term direct marketing is defined by two perspectives (cf. http://www.marketingpower.com):

- Retailing Perspective: "A form of non-store retailing in which customers are exposed to merchandise through an impersonal medium and then purchase the merchandise by telephone or mail."

- Channels of Distribution Perspective: "The total of activities by which the seller, in effecting the exchange of goods and services with the buyer, directs efforts to a target audience using one or more media (direct selling, direct mail, telemarketing, direct-action advertising, catalog selling, cable selling, etc.) for the purpose of soliciting a response by phone, mail, or personal visit from a prospect or customer."

The former perspective highlights the nexus of direct marketing to multimedia, because multimedia, and particularly networks such as the Internet and the World Wide Web, is the modern surrogate of human salespeople praising products and services. However, multimedia and networks might be used to offer additional value to customers. The latter perspective emphasizes the advantage provided by modern multimedia technologies: immediate buying without changing the medium. There are several terms for this, proposed in the literature, with respect to particular media such as "e-mail marketing," "Internet marketing," and "mobile marketing" (via cellular phones, PDAs, etc.). Thanks to this advantage, direct marketing using multimedia technologies stands out from the crowd of market- 
Table 1. Domains and tasks of accomplishing direct marketing with multimedia and networks

\begin{tabular}{|c|c|c|c|}
\hline Domain & Task & Value created for the customer & Benefit for supplier \\
\hline \multirow[t]{4}{*}{ Product } & Innovation & Better products and services & $\begin{array}{l}\text { Reputation as credible } \\
\text { competitor and maintaining } \\
\text { long-term profits }\end{array}$ \\
\hline & (Mass) Customization & Individual needs are catered for & Superior offers \\
\hline & Interactive services & $\begin{array}{l}\text { Feeling to be an important element of } \\
\text { market interchange }\end{array}$ & $\begin{array}{l}\text { Gain of information on cus- } \\
\text { tomers' preferences }\end{array}$ \\
\hline & $\begin{array}{l}\text { Providing additional infor- } \\
\text { mation }\end{array}$ & $\begin{array}{l}\text { Additional information on usage as } \\
\text { well as quality assessment (e.g., con- } \\
\text { sumer reports) }\end{array}$ & Improved quality perception \\
\hline \multirow[t]{2}{*}{ Price } & Adaptive pricing & $\begin{array}{l}\text { Buying with the confidence of a fair } \\
\text { market price }\end{array}$ & $\begin{array}{l}\text { Avoiding overpricing as } \\
\text { well as underpricing }\end{array}$ \\
\hline & $\begin{array}{l}\text { Maintaining current price } \\
\text { information }\end{array}$ & $\begin{array}{l}\text { Impression of price movements in the } \\
\text { course of time }\end{array}$ & $\begin{array}{l}\text { Reputation as active pricing } \\
\text { vendor }\end{array}$ \\
\hline \multirow[t]{2}{*}{ Promotion } & $\begin{array}{l}\text { Enabling a dialogue with } \\
\text { and between the customers }\end{array}$ & $\begin{array}{l}\text { Admitted to communicate his or her } \\
\text { needs and wants }\end{array}$ & $\begin{array}{l}\text { Gaining information on an } \\
\text { individual level }\end{array}$ \\
\hline & $\begin{array}{l}\text { Achieving a share of voice } \\
\text { in modern communication } \\
\text { environments }\end{array}$ & $\begin{array}{l}\text { Keeping informed about offers, innova- } \\
\text { tive products, and services }\end{array}$ & $\begin{array}{l}\text { Being recognized by the } \\
\text { buyers }\end{array}$ \\
\hline \multirow[t]{2}{*}{ Place } & $\begin{array}{l}\text { Maintaining convenient } \\
\text { access }\end{array}$ & $\begin{array}{l}\text { Reduced transaction costs, saving time, } \\
24 / 7 \text { shopping }\end{array}$ & $\begin{array}{l}\text { Cutting costs for shops, } \\
\text { staff, and so forth; } \\
24 / 7 \text { trade; overcoming geo- } \\
\text { graphical restrictions }\end{array}$ \\
\hline & $\begin{array}{l}\text { Maintaining online pay- } \\
\text { ment security }\end{array}$ & Aplomb self perception & $\begin{array}{l}\text { Recognition of trustworthi- } \\
\text { ness }\end{array}$ \\
\hline \multirow[t]{2}{*}{$\begin{array}{l}\text { Relationship } \\
\text { management }\end{array}$} & $\begin{array}{l}\text { Fostering and supporting } \\
\text { the user or buyer com- } \\
\text { munity }\end{array}$ & Becoming part of a community & $\begin{array}{l}\text { Increased buyer loyalty; } \\
\text { own products and services } \\
\text { might become part of buyers } \\
\text { self-concepts }\end{array}$ \\
\hline & $\begin{array}{l}\text { Keeping up-to-date on } \\
\text { buyers' opinions, actions, } \\
\text { and interests }\end{array}$ & $\begin{array}{l}\text { Becoming a partner rather than a cus- } \\
\text { tomer }\end{array}$ & Inimitability \\
\hline
\end{tabular}

ing techniques. Some authors propose to enrich the elements of the classical marketing with e-marketing components, but more detailed investigations suggest that the recent changes are more fundamental than just blending the marketing mix with an electronic mix (e.g., Kalyanam \& McIntyre, 2002; Verona \& Prandelli, 2002). All marketing concepts mentioned previously have to cope with the tasks of conventional marketing, which are commonly broken down into the domains of product, price, place, and promotion. Table 1 depicts a scheme of tasks that direct marketers have to accomplish in order to tap the full potential of multimedia and networks.

Subsequently, the domains depicted in Table 1 guide the discussion on opportunities and challenges market- ers are facing when adopting multimedia technologies to their marketing mix.

\section{Product}

Multimedia technologies help develop the creation of innovative products and new service components into well-established products. For instance, online newspapers are a product innovation as well as an additional element to the conventional newspaper offer (which should lead to higher customer loyalty in the future). Therefore, multimedia technologies enhance a company's reputation as a credible competitor, and thus help to maintain long-term profits. Developments in Web technology enable firms and marketers to satisfy 
Figure 1. Product customization using multimedia technology

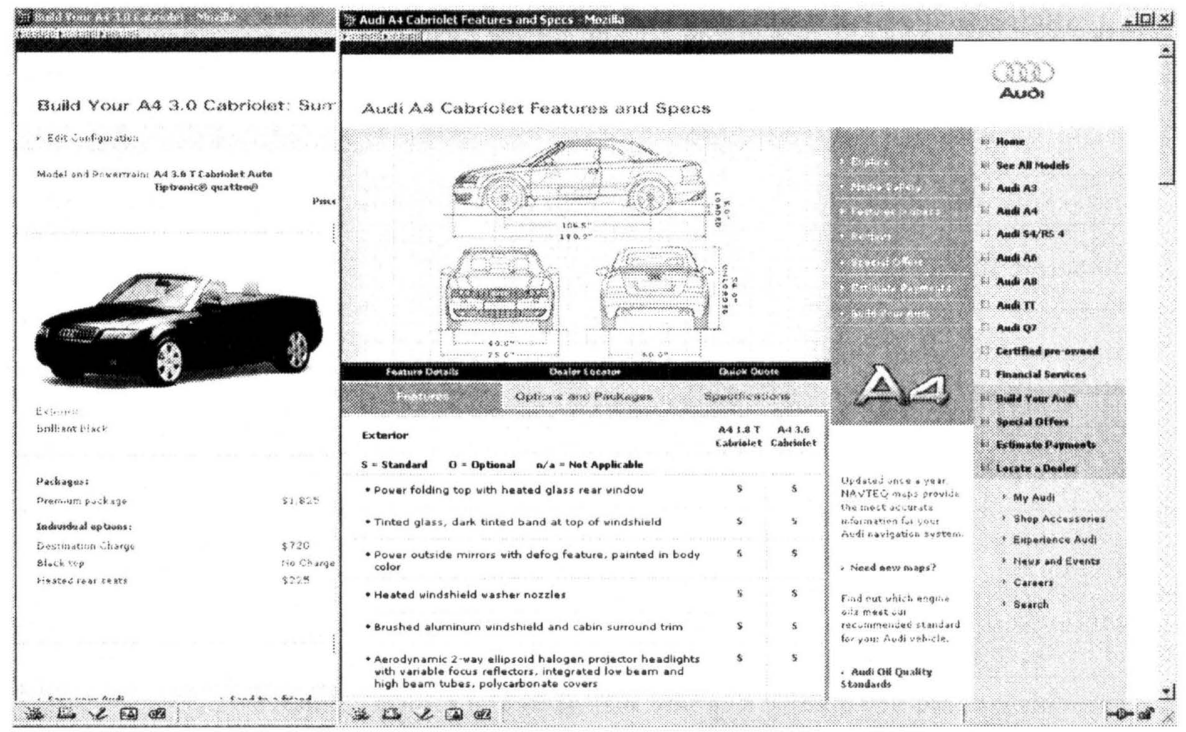

individual needs of the customer and provide superior offers. In the literature, this is called mass customization . An example is depicted in Figure 1, where an automotive vendor enables customers and salespeople to equip a new car according to individual preferences interactively. The vendor uses computer-aided manufacturing based on these personalized specifications.

While the problem of information overload is intensified by the availability of a tremendous amount of product information, one-to-one marketing and other personal services should help the customer to identify products according to their interests. This calls for the provision of personalized product recommendations (Gaul \& Schmidt-Thieme, 2002).

\section{Price}

One-to-one transactions of manufacturers and consumers over the Web provide the manufacturer with the opportunity to return to individual price settings (adaptive pricing). Price differentiation can be defined as a strategy to sell the same product to different consumers at different prices. On the basis of the firm's estimation, prices are differentiated according to customer's individual willingness to pay. Name-your-own-price is a price mechanism where the buyer, not the seller, determines the price by making a bid for a product or service. The seller can then either reject or accept the bid. In the case of rejection, the consumer is not allowed to bid again within a certain time span. A screenshot of the most prominent provider of such a price mechanism, Priceline (www.priceline.com), is shown in Figure 2. At Priceline, potential buyers can bid for rental cars, hotel accommodation, holidays and flights, and so forth. Spann, Skiera, and Schäfers (2004) advise sellers to think carefully about the design of the name-yourown-price mechanism, because restricting consumers to a single bid is likely to reduce revenues.

As a second mechanism, online auctions can be used as marketing instruments in order to communicate, advertise or sell products, or even to determine customers' willingness to pay. Both mechanisms enable suppliers to adjust prices very quickly and, thus, transmit price fluctuations to the customers. This advantage cancels out direct marketers' obstacle of price rigidity, whereas, for example, printed catalogs are valid for a time period.

\section{Promotion}

The Internet is an advertising medium that is in competition with traditional media, and one that may combine the advantages of various media with respect to the form of advertising. Advertising on the Web can be compared with advertising on television, which provides dynamic, short-term exposures with low information by using 
Figure 2. Screenshot from www.priceline.com

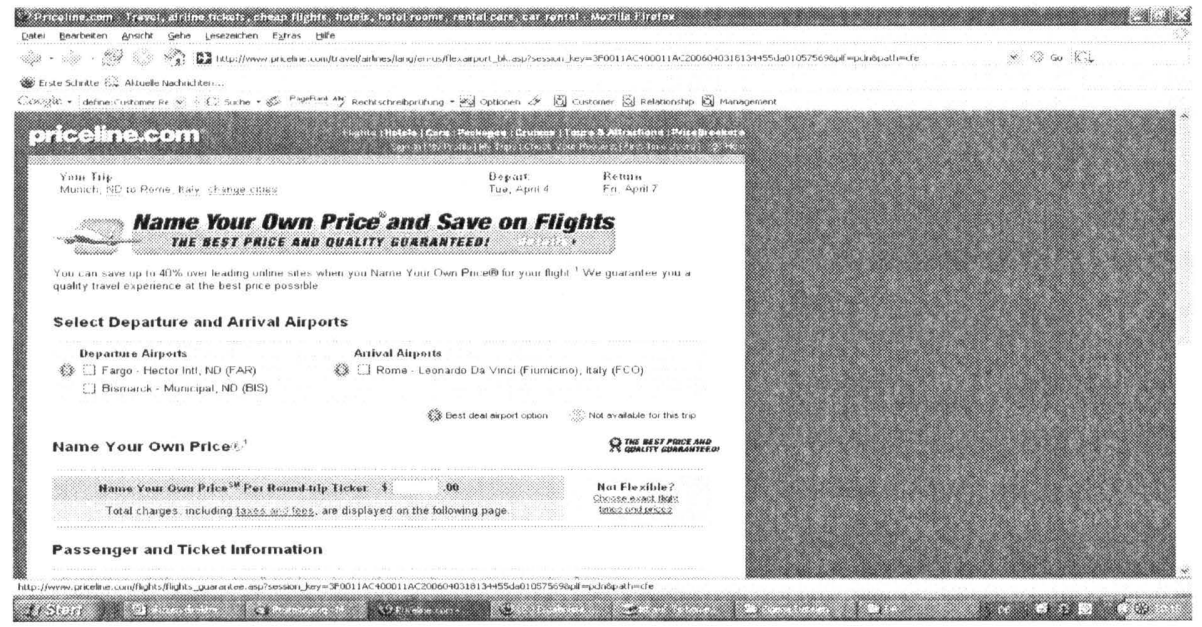

video and audio formats, or it can be similar to static, relatively long-term exposures with high information, as in print media. It is emerging as an adaptive, hybrid medium with respect to audience addressability, audience control, and contractual flexibility. The success of the Internet as a marketing channel depends on the advantages that the technology can offer concerning interactivity and customizability, thus diminishing information asymmetry between buyers and sellers. Well-established forms of Internet advertising are banners, micro sites, e-mail, newsletters, and viral mail, which provide a powerful and inexpensive means of organizing and distributing advertising messages.

\section{Place}

Unlike supermarkets, department stores, or even catalogs, the Internet possesses several unique characteristics that have the potential to benefit consumers in several ways. One obvious advantage is that the Internet enables access independent of consumers' local markets, 24 hours a day, seven days a week. Medium-sized enterprises can compete with large ones by expanding their traditional distribution channels. Thanks to the lower searching costs, consumers can consider thousands of product alternatives and therefore may feel stressful with regard to the enormous possibilities of online shopping when they try to find the product that best fits their needs.

\section{RELATIONSHIP MANAGEMENT IN THE FRAMEWORK OF CONTENT, COMMERCE, AND COMMUNITY}

A popular wise expression in the Internet industry is "Content is king," but with respect to the aim of marketing content by mean of offering text, artwork, animation, and music in multimedia environments does neither create profits nor a competitive advantage for the vendors.

The community is made up by providing content on Web sites, discussion groups, newsgroups, and even in chat rooms. Clearly, the vendors take responsibility to provide the community with technical facilities to support virtual user groups, brand communities, and so forth. Both content and community are making up the vendors affiliation based on trust and social capital (Evans \& Wurster, 1999). In these communities every person is a recipient and a sender. The Internet changes the way of communicating, working, learning, and even of thinking. Stewart and Pavlou (2002) argue the level of interactivity to determine the quality of marketing communication. Moreover, the Internet enables a dialogue with, as well as between, the customers, which might be the most significant distinction from most traditional media. Thus, consumers become active participants of the direct marketing process.

The most prominent example of communities' impact on direct marketing in multimedia environments is 
Table 2. Comparison of direct marketing techniques

\begin{tabular}{|l|l|l|l|l|l|}
\hline & Direct Mail & Telephone & E-mail & SMS & $\begin{array}{l}\text { Automated } \\
\text { IP-telephone }\end{array}$ \\
\hline Reach & $\begin{array}{l}\text { All house- } \\
\text { holds }\end{array}$ & $\begin{array}{l}\text { Most } \\
\text { households }\end{array}$ & Internet users & $\begin{array}{l}\text { Young and } \\
\text { middle-aged }\end{array}$ & Innovators \\
\hline Cost & Medium & High & Very low & Low & Low \\
\hline Time to organize & $\begin{array}{l}\text { Slowest- } \\
\text { materials, } \\
\text { post }\end{array}$ & $\begin{array}{l}\text { Slow- } \\
\text { scripting, } \\
\text { briefing }\end{array}$ & Quick & Quick & Quick \\
\hline List availability & Very good & Good & Limited & Very Limited & Excellent \\
\hline Response time & Slow & Quick & Quick & Quickest & Quick \\
\hline Materials & Any & Voice only & $\begin{array}{l}\text { Text, visuals, } \\
\text { animations }\end{array}$ & $\begin{array}{l}\text { Text, visuals, } \\
\text { animations }\end{array}$ & $\begin{array}{l}\text { Voice, video, } \\
\text { animations }\end{array}$ \\
\hline Personalization & Yes & One-to-one & Yes & Yes & Yes \\
\hline Persuasive impact & Medium & High & Low & Low & Medium \\
\hline Interactivity & No & Yes & Yes & Yes & Yes \\
\hline
\end{tabular}

collaborative filtering. It identifies consumers' wishes by automating the process of "word-of-mouth," by which people recommend products or services to others (Herlocker, Konstan, Terveen, \& Riedl, 2004). The basic mechanism behind collaborative filtering systems is to register a multitude of consumer preferences, use a similarity metric to select a subgroup of people whose preferences are similar to those of the person seeking advice, calculate an average of the subgroup's preferences, and recommend options on which the advice-seeker has so far expressed no personal opinion. Typically, collaborative filtering is used to give recommendations of books, CDs, or movies in online stores. Virtual communities are a promising concept because community building contains the force of purchasing power concentration in relatively homogeneous target groups, enables comprehensive individual marketing, and establishes entrance barriers to other suppliers. The dynamic communication about products and services involves well-informed community members and allows for constant tracking of user preferences as well as keeping up-to-date on buyer opinions, actions, and interests. Additionally, virtual communities could enhance buyer loyalty, while the products and services become part of buyers' self-concepts. Verona and Prandelli (2002) argue the affiliation to foster the cognitive dimension of loyalty.

The third component of the $3 \mathrm{Cs}$, commerce, refers to all attempts to increase buyer loyalty, by Web-based capabilities that help companies to organize and manage customer relationships. The interaction with each customer is likely to become a series of linked interactions, so that with each interaction, offerings can more closely meet the customer's needs (Kalyanam \& McIntyre, 2002).

Technical features of the offered products or services, particularly incompatibilities, might be used to increase customer loyalty by creating a lock-in situation, which avoids customers churn on the Web. Since the lock-in mostly does not create a mutual benefit, this strategy should be carefully merged with affiliation to increase the customer loyalty.

\section{FUTURE DEVELOPMENTS}

Since the technology is still evolving heavily and direct marketers are usually among the first user groups adopting new technologies, the future development can hardly be described by extrapolating previous developments. To provide an impression, we discuss two examples subsequently.

\section{Example 1: Personalized Advertising in Digital TV Environments}

With the expansion of digital TV and set-top boxes, several hundreds of alternative TV programs can be 
watched by consumers. Due to the plurality of information content, people are faced with information overload, which is comparable to that of the Internet. With regard to the abundance of digital content and by adopting a consumer-centric focus, businesses recognize the importance of applying personalization techniques over interactive television. This should, on the one hand, provide the flexibility for consumers to filter information on TV events according to their interests. On the other hand, advertising companies can tailor commercials and their respective interactive content to each individual viewer profile (Chorianopoulos \& Spinellis, 2004).

\section{Example 2: Mobile Telephony as a Tool of Direct Marketing}

Today, the number of mobile telephones exceeds that of fixed telephones, and therefore mobile phones appear to be the essential tool of communication for most consumers. Mobile phones, being in constant reach of their users and being available in many everyday situations, provide continuous wireless connectivity, which shows promise for direct marketing. The advent of mobile phones, PDAs and other handheld devices in direct marketing has driven research toward the investigation of the influence that these new technologies have on the relationship with customers. In the literature, this is referred to as mobile marketing (Dickinger, Haghirian, Murphy, \& Scharl, 2004). A variety of services have been developed for mobile Internet applications, such as Web information search, SMS, MMS, banking, chat, or weather forecasts, which are used in m-commerce (Okazaki, 2005).

In mobile marketing, SMS can be used in a push or pull mode of advertising and may be perceived as content or as ads, and this can blur the line between advertising and service (Dickinger et al., 2004). Compared to other direct marketing techniques, SMS possesses some unique advantages such as very quick response times and everywhere access. A short comparison of direct marketing techniques is given in Table 2.

Scharl, Dickinger, and Murphy (2005) investigate SMS marketing via content analysis of 500 global Web sites and qualitative interviews. They identify content, personalization, and consumer control as message success factors (see Table 3), and device technology, transmission process, product fit, and media cost as media success factors of SMS marketing.

A relatively new idea to extend the capabilities of mobile marketing is to use built-in cameras of consumer mobile phones as sensors for two-dimensional visual codes. Camera-phones perform image processing tasks on the device itself and use the results as additional user input. The codes are attached to physical objects, printed documents, and virtual objects displayed on electronic screens and provide object-related informa-

Table 3. Success factors of SMS marketing

\begin{tabular}{|l|l|l|}
\hline Success factor & Description & Example/Explanation \\
\hline Content & $\begin{array}{l}\text { Funny, entertaining, eye-catching, and } \\
\text { informative content }\end{array}$ & $\begin{array}{l}\text { SMS might be more effective in com- } \\
\text { municating prices or new services than } \\
\text { physical products }\end{array}$ \\
\hline Personalization & $\begin{array}{l}\text { Include consumer's habits, interests, } \\
\text { and preferences to target the ads }\end{array}$ & $\begin{array}{l}\text { Personal information such as leisure } \\
\text { activities, holidays, music, and media } \\
\text { interests }\end{array}$ \\
\hline Consumer Control & $\begin{array}{l}\text { Custumers give prior permission before } \\
\text { contact and can stop messages at any } \\
\text { time }\end{array}$ & $\begin{array}{l}\text { Restrictions apply to unapproved mes- } \\
\text { sages in many countries }\end{array}$ \\
\hline Device Technology & $\begin{array}{l}\text { Design attractive messages by new tech- } \\
\text { nologies (MMS, animations) }\end{array}$ & $\begin{array}{l}\text { Heterogeneous screen sizes and displays } \\
\text { hamper the implementation }\end{array}$ \\
\hline Transmission Process & $\begin{array}{l}\text { Text messages should arrive a few min- } \\
\text { utes after sending to guarantee context } \\
\text { dependency }\end{array}$ & $\begin{array}{l}\text { For example, notifying travellers of } \\
\text { flight status via SMS }\end{array}$ \\
\hline Product Fit & $\begin{array}{l}\text { SMS is particularly useful for technical } \\
\text { goods and services }\end{array}$ & $\begin{array}{l}\text { For example, announce events or sup- } \\
\text { port of product launches }\end{array}$ \\
\hline
\end{tabular}


tion. Used as sensors for real-world objects, mobile phones can narrow the gap between the physical and the virtual world by enabling customers to collect data in everyday situations (Rohs, 2004). This application multiplies the opportunities for m-commerce as well as for $\mathrm{m}$-advertising.

\section{CONCLUSION}

This article outlines the opportunities and the challenges brought to direct marketers by new multimedia technologies. The innovative technologies affect all four domains (4P) of classical marketing mix management and enable the creation of mutual benefits. Moreover, the technological interactivity brings a new quality in the relationship management for direct marketers. The affiliation of the contents provided by the vendors to a particular community needs to be fitted to the extent of lock-in features used to foster the customer retention. Using the examples of (1) personalized advertising in digital TV environments and (2) mobile telephony, we illustrate the future developments of direct marketing with multimedia technologies.

The article comprises a synoptic overview of the tasks, the benefits for the vendors, and the values to be created for the customers. Different direct marketing techniques using multimedia technologies are systematized, and the key success factors of SMS marketing are summarized.

\section{REFERENCES}

American Marketing Association. (2006). Retrieved September 29, 2006, from http://www.marketingpower. com/mg-dictionary-view1061.php

Burke, R. R. (2002). Technology and the customer interface: What consumers want in the physical and virtual store. Journal of the Academy of Marketing Science, 30(4), 411-432.

Chorianopoulos, K., \& Spinellis, D. (2004). User interface development for interactive television: Extending a commercial DTV platform to the virtual channel API. Computers \& Graphics, 28(2), 157-166.

Coviello, N. E., Milley, R., \& Marcolin, B. (2003). Understanding IT-enabled interactivity in contem- porary marketing. Journal of Interactive Marketing, 15(4), 18-33.

Dickinger, A., Haghirian, P., Murphy, J., \& Scharl, A. (2004). An investigation and conceptual model of SMS marketing. In H. Ralf Jr. (Ed.), Proceedings of the $37^{\text {th }}$ Hawaii International Conference on System Sciences (pp. 31-41). Big Island, Hawaii: IEEE Computer Society Washington.

Evans, P., \& Wurster T. S. (1999). Blown to bits: How the new economics of information transforms strategy. Boston: Harvard Business School Press.

Gaul, W., \& Schmidt-Thieme, L.(2002). Recommender systems based on user navigational behavior in the Internet. Behaviormetrika, 29(1), 1-22.

Herlocker, J. L., Konstan, J. A., Terveen, L. G., \& Riedl, J. T. (2004). Evaluating collaborative filtering recommender systems. ACM Transactions on Information Systems, 22(1), 5-53.

Kalyanam, K., \& McIntyre, S. (2002). The e-marketing mix: A contribution of the e-tailing wars. Journal of the Academy of Marketing Science, 30(4), 487-499.

Noe, T., \& Parker, G. (2005). Winner take all: Competition, strategy, and the structure of returns in the Internet economy. Journal of Economics \& Management Strategy, 14(1), 141-164.

Okazaki, S. (2005). New perspectives on m-commerce research. Journal of Electronic Commerce Research, 6(3), 160-164.

Rohs, M. (2004). Real-world interaction with cameraphones. In H. Murakami, H. Nakashima, H. Tokuda, \& M. Yasumura (Eds.), Second International Symposium on Ubiquitous Computing Systems (UCS 2004), Tokyo (pp. 74-89).

Scharl, A., Dickinger, A., \& Murphy, J. (2005). Diffusion and success factors of mobile marketing. Electronic Commerce: Research and Applications, 4(2), 159-173.

Spann, M., Skiera, B., \& Schäfers, B. (2004). Measuring individual frictional costs and willingness-to-pay via name-your-own-price mechanisms. Journal of Interactive Marketing 18(4), 22-36. 
Stewart, D., \& Pavlou, P. (2002). From consumer response to active consumer: Measuring the effectiveness of interactive media. Journal of the Academy of Marketing Science, 30(4), 376-397.

Verona, G., \& Prandelli, E. (2002). A dynamic model of customer loyalty to sustain competitive advantage on the Web. European Management Journal, 20(3), 299-309.

\section{KEY TERMS}

Collaborative Filtering: A collective method of recommendation based on previously gathered information to guide people's choices of what to read, what to look at, what to watch, and what to listen to.

Customer Relationship Management (CRM): The systematic collection and utilization of business data to manage interactions with customers by identifying patterns and interests of customers as success factors in order to foster customer loyalty through individualized correspondence and tailored offers.
Direct Marketing: A direct communication to a customer or business by one or more media that are designed for the purpose of soliciting a response in the form of an order, a request for further information, or a personal visit from a customer.

Mass-Customization: Provides customized offers based on individual needs by the use of flexible computer-aided manufacturing systems in order to combine low unit costs of mass production with the flexibility of individual customization.

Mobile Marketing: Adding value to the customers and enhancing revenue by distributing any kind of message or promotion on mobile devices.

Price Differentiation: A pricing strategy to sell the same product to different consumers at different prices based on the customer's estimated economic value of an offering.

SMS Marketing: Using short messages services (SMS) to provide customers with time and location sensitive, personalized information to promote goods and services.

\section{M}

